\title{
ANALISA TEKNIK PENGUKURAN KEPUASAN PELANGGAN PADA PT GRAMEDIA ASRI MEDIA (REGIONAL I TB.GRAMEDIA BALEKOTA)
}

\author{
Joko Hardono ${ }^{1)}$, Henri Ponda ${ }^{2)}$, Devi Setyaningsih ${ }^{3)}$ \\ ${ }^{1,2,3)}$ Program Studi Teknik Industri, Fakultas Teknik \\ Universitas Muhammadiyah Tangerang \\ Jl. Perintis Kemerdekaan I/33 Cikokol, Kota Tangerang \\ E-mail : jhardono@yahoo.com, henri_ponda@umt.ac.id
}

\begin{abstract}
A b s tract
This research proposes Analysis of Customer Satisfaction Measurement Techniques At PT Gramedia Asri Media (Regional I TB.Gramedia Balekota) the purpose of this research is to find out what aspects are used by PT. Gramedia Balekota to assess customer satisfaction and analyze customer satisfaction assessment techniques applied by PT. Gramedia Balekota at this time. The research method used in this study is the method of observation, interview, questionnaire, and literature study. Comparing the current method to Servqual Method with five aspects of customer satisfaction, namely Tangible, Reliability, Responsivenessi, Assurance, and Empaty. From the results of questionaire satisfaction of TB customers. Gramedia Period period January 2018-May 2018 obtained results A total of 189 respondents gave an assessment of Sad Emoticon, a total of 205 respondents gave an Emoticon flat rating, and as many as 106 respondents gave an assessment of Smile Emoticon. The aspect of customer satisfaction assessment included in TB. Gramedia Balekota in it's questionnaire to measure customer satisfaction. TB.Gramedia Balekota only uses three indicators, namely product availability, shopping convenience, and product quality. Product availability and product quality enter the tangible aspect. And the convenience of shopping goes into the Reliability aspect. So that in measuring the satisfaction of TB customers, Gramedia Balekota has not fulfilled the five aspects of service quality.
\end{abstract}

Key words : Measurement, customer satisfactions, Servqual Method, service quality.

\section{PENDAHULUAN}

Semakin pesatnya pertumbuhan teknologi dan informasi dan semakin ketatnya persaingan bisnis, menjadi faktor pendorong semkin ketatnya tuntutan pelanggan. Kesadaran dunia usaha bahwa pelanggan merupakan aset terbesar yang harus dijaga maka dunia usaha akan selalu berupaya senantiasa untuk meningkatkan kualitas pelayanan terhadap pelanggan. Kualitas pelayanan merupakan aspek yang dapat membedakan dan membuat unggul suatu perusahaan dengan para pesaingnya. Kualitas pelayanan juga merupakan indikator utama dalam sebuah pelayanan kepada pelanggan.

Kualitas pelayanan memberikan dorongan kepada pelanggan untuk menjalin ikatan yang kuat dengan perusahaan, dan dalam jangka panjang ikatan ini memungkinkan perusahaan untuk memahami dengan seksama harapan dan kebutuhan pelanggannya, dengan demikian perusahaan dapat meningkatkan kepuasan pelanggan melalui pemaksimalan pelayanan pelanggan. Kualitas pelayanan yang baik akan menciptakan kepuasan pelanggan, dan ini dapat mempengaruhi intensitas kunjungan pelanggan pada kesempatan berikutnya.

Kualitas pelayanan adalah seberapa jauh perbedaan antara kenyataan dan harapan pelanggan atas pelayanan yang diterima.Apabila pelayanan yang diterima atau dirasakan sesuai dengan harapan pelanggan, maka kualitas pelayanan dipersepsikan baik dan memuaskan.Jika pelayanan yang diterima melampaui harapan pelanggan, maka kualitas pelayanan dipersepsikan sebagai kualitas yang ideal.Sebaliknya jika pelayanan yang diterima lebih rendah daripada yang diharapkan, maka kualitas pelayanan dipersepsikan buruk. 
Dalam memberikan pelayanan yang berkualitas sebagai usaha untuk memenuhi kebutuhan dan harapan pelanggan, perusahaan dapat berpedoman pada dimensi kualitas pelayanan - Aadapundimensi kualitas pelayanan menurut Servqual meliputi bukti fisik (tangible), kehandalan (reliability), daya tanggap (responsiveness), jaminan (assurance), dan empati (empathy).

Toko Buku Gramedia Balekota.PT Gramedia Asri Media adalah anak perusahaan kelompok Kompas Gramedia yang menyediakan jaringan Toko Buku Gramedia dibeberapa Kota di Indonesia. Dalam upaya memberikan pelayan kepada pelanggan PT Gramedia Asri Media memiliki nila keutamaan perusahaan (nilai) yang terdiri dari lima sifat yang dikenal dengan 5C, yaitu Caring, Creadible, Competent, Competitiv, CostumerDelight. Kelima nilai ini ditetapkan sebagai pedoman prilaku karyawan dalam berfikir, bersikap, dan bertindak.

Selama tahun 2016-2017 penjualan Toko Buku Gramedia Balekota mengalami penurunan jumlah pengunjung. Penurunan pengunjung dipengaruhi oleh beberapa faktor seperti adanya perusahaan pesaing seperti Toko buku Intermedia dan Gunung Agung serta kualitas pelayanan kepuasaan pelanggan dari Toko Buku Gramedia yang masih kurang memuaskan.

Berdasarkan ulasan diatas, penulis bermaksud melakukan penelitian terhadap teknik pengukuran kepuasaan pelanggan pada PT. Gramedia Asri Media melalu judul: “Analisa Teknik Pengukuran Kepuasan Pelanggan Pada PT Gramedia Asri Media Balekota”.

\section{METODE PENELITIAN}

\section{Jenis penelitian}

Metode penelitian yang digunakan adalah metode penelitian kualitatif dengan analisis dekriptif. Penelitian ini dilakukan dengan melukiskan dan menerangkan fakta, Menyimpulkan informasi aktual secara rinci dengan melukiskan gejala dari informasi yang ditemukan dilapangan.

\section{Sumber dan Teknik Pengambilan Data}

Jenis dan sumber data penelitian ini adalah:

a. Data Primer, adalah data hasil observasi, wawancara dan dokumentasi.

b. Data sekunder bersumber dari peraturan/SOP perusahaan, buku literature, jurnal ilmiah, dan sejarah perusahaan

Teknik pengumpulan data yang digunakan dalam penelitian ini adalah:

a. Studi Kepustakaan, yaitu dengan cara mempelajari buku-buku, literatur, dan segala macam bacaan yang berhubungan dengan permasalahan yang diteliti.

b. Studi Lapangan, yaitu dengan cara interview (wawancara)

c. Observasi, yaitu dengan melakukan pengamatan di toko buku Gramedia Balekota.

\section{Rumusan Masalah}

Berdasarkan uraian latar belakang masalah di atas, perumusan masalah yang dikemukakan dalam penelitian ini adalah:

Apakah teknik pelayanan kepuasan pelanggan yang diterapkan oleh PT. Gramedia Asri Media saat ini sudah mampu memberikan masukan data yang optimal ?

\section{Tujuan Penelitian}

Tujuan Penelitian Berdasarkan latar belakang dan perumusan masalah, maka yang menjadi tujuan penelitian ini adalah sebagai berikut :

Menganalisa efektivitas teknik Pelayanan kepuasan pelanggan yang diterapkan oleh PT. Gramedia Asri Media saat ini. 


\section{HASIL DAN PEMBAHASAN}

\section{Penurunan Jumlah Pengunjung}

Selama tahun 2018 Pengunjung Toko Buku Gramedia Balekota mengalami penurunan jumlah pengunjung. Pengunjung Toko Buku Gramedia yang mengalami penurunan dipengaruhi oleh beberapa faktor seperti adanya perusahaan pesaing seperti Toko buku Intermedia dan Gunung Agung serta kualitas pelayanan dari Toko Buku Gramedia yang masih kurang memuaskan. Berikut adalah data pengunjung periode Januari 2018-Mei 2018.

Tabel 1. Jumlah Pengunjung TB. Gramedia Balekota

\begin{tabular}{|c|c|}
\hline \multicolumn{2}{|c|}{ Jumlah Pengunjung } \\
Periode Januari 2018 - Mei 2018 \\
\hline Bulan & Jumlah pengunjung \\
\hline Januari & 8,094 \\
\hline Febuari & 7,587 \\
\hline Maret & 7,183 \\
\hline April & 6,370 \\
\hline Mei & 6,035 \\
\hline
\end{tabular}

Sumber: TB. Gramedia Balekota.

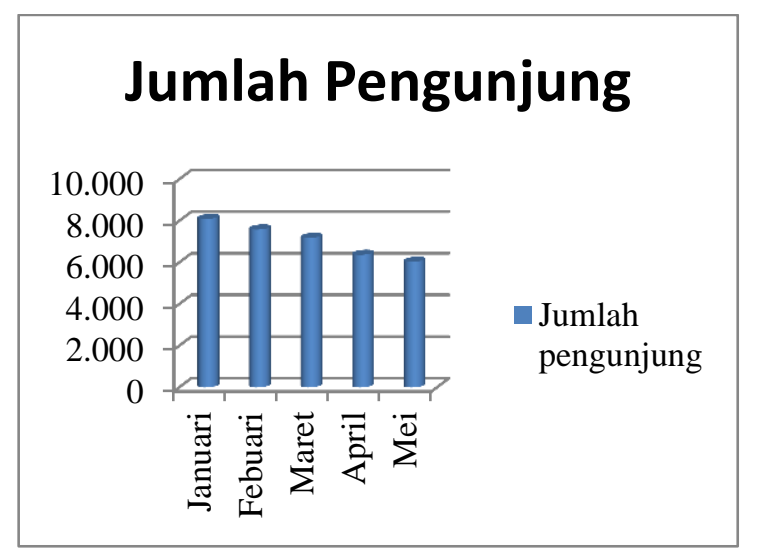

Gambar 1. Jumlah Data Pengunjung TB.Gramedia Balekota

Sumber: TB. Gramedia Balekota

\section{Pengukuran Kepuasan Pelanggan TB.Gramedia Balekota}

Untuk mengetahui apakah pelanggan merasa puas atau tidak terhadap pelayanan yang diterima, TB. Gramedia Balekota memberikan kuisioner kepada 100 pelanggan secara acak. Adapun kuisioner. Berikut ini adalah standart yang sudah ditetapkan TB.Gramedia Balekota bagi setiap karyawan dalam memberikan kuisioner kepada pelanggan:

a. Senyum, Sapa, Salam:

"Salam Inspirasi. Dengan saya .... (memperkenalkan diri) mohon maaf mengganggu waktu berbelanjanya".

b. Menjelaskan tata cara mengisi kuisioner:

"Bagaimana menurut Bapak/Ibu tentang pelayanan yang di berikan oleh Toko Buku Gramedia Balekota?"

"Berikan penilaian Bapak/Ibu tentang ketersediaan produk, kenyamanan berbelanja, dan kualitas produk di TB.Gramedia Balekota?"

"Dari ketiga Emoticon ini Bapak/Ibu dapat memilih salah satunya untuk dijadikan penilaian bagi TB.Gramedia Balekota". 


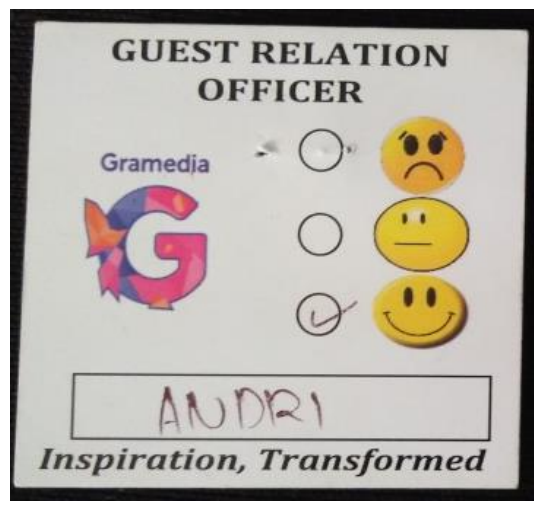

Gambar 2. kartu penilaian kepuasaan pelanggan

Sumber: TB.Gramedia Balekota

Ukuran kepuasaan pelanggan dikatagorikan menjadi tiga golongan yaitu :

a. Emoticon Sad menggambarkan penilaian yang buruk atau rasa kecewa.

b. Emoticon Flat menggambarkan penilaian yang netral atau biasa saja,

c. Emoticon Smile menggambarkan penilaian yang memuaskan.

Hasil kuisioner terhadap kepuasaan pelanggan TB.Gramedia pada periode Januari 2018 s/d Mei 2018 :

Tabel 2. Data kepuasaan pelanggan

\begin{tabular}{|c|c|c|c|}
\hline \multicolumn{4}{|c|}{ Data kepuasan pelanggan } \\
Periode Januari 2018 s/d Mei 2018 \\
\hline & $\oplus$ & - & ○ \\
\hline Januari & 30 & 40 & 30 \\
\hline Febuari & 33 & 41 & 26 \\
\hline Maret & 39 & 42 & 19 \\
\hline April & 42 & 38 & 20 \\
\hline Mei & 45 & 44 & 11 \\
\hline
\end{tabular}

Sumber: TB. Gramedia Balekota

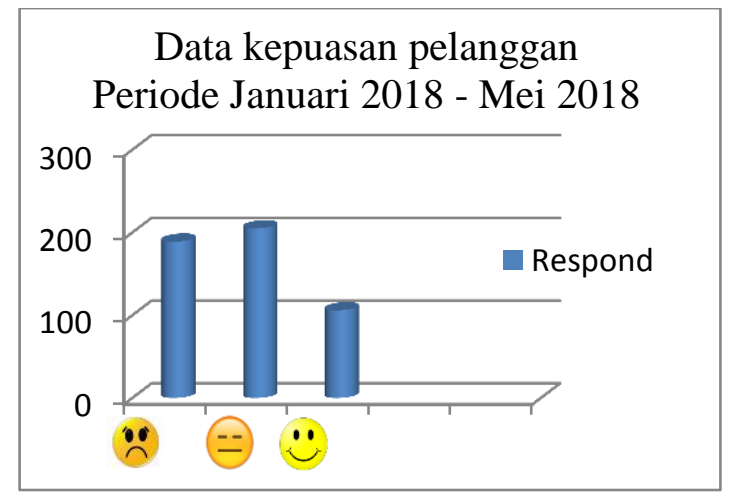

Gambar 3. Data Kepuasan Pelanggan

Sumber:TB. Gramedia Balekota 
Grafik tersebut menyatakan sebagai berikut:

a. Sebanyak 189 responden memberikan penilaian Emoticon Sad

b. Sebanyak 205 responden memberikan penilaian Emoticon flat.

c. Dan, sebanyak 106 responden memberikan penilaian Emoticon Smile

Indikator yang digunakan TB.Gramedia Balekota dalam mengukur kepuasan pelangggan hanya menggunakan Emoticon saja. Emotikon hanya memberikan informasi tentang perasaan pelanggan, apakah senang, biasa saja atau sedih, sehingga sulit untuk melakukan perbaikan dalam meningkatkan kepuasan pelangan. Misalnya Emoticon Sad yang mengalami peningkatan disetiap bulannya. Tidak dapat diketahui hal apa yang membuat kepuasaan pelanggan menurun. Karena simbol rasa sedih tersebut mengandung banyak arti, apakah dalam segi produk yang kurang memuaskan, karyawan yang tidak ramah, lingkungan berbelanja yang kotor dan sebagainya.

\section{Nilai dasar prilaku karyawan}

Dalam rangka memberikan pelayanan yang maksimal untuk meningkatkan kepuasaan pelanggan, TB.Gramedia Balekota memberikan pembekalan tentang 5 prinsip dasar dalam prilaku karyawan dalam berfikir, bersikap, dan bertindak.terdiri dari lima sifat yang dikenal dengan $5 \mathrm{C}$ (Caring, Creadible, Competent, Competitiv, Costumer Delight).

\section{A. Caring}

a Humanisme/kemanusiaan, yaitu menghargai manusia sesuai harkat \& martabatnya yang berdasarkan keyakinan akan yang tertinggi yang mengatasi segala sesuatu (transcendental).

b Peduli pada sesama, compassion, membantu dengan tulus.

c Tanggungjawab sosial (CSR); cepat tanggap terhadap problem lingkungan kemasyarakatan.

d Memberikan kesempatan yang sama pada setiap orang tanpa membedakan golongan, ras, suku, gender, agama.

e Menghargai perbedaan budaya; adaptif; inkulturatif; cross-cultural.

f Management by walking around; saling menyapa; mengenal satu sama lain.

g aling menghargai, saling memahami (toleransi).

h Peduli pada kesejahteraan karyawan; membina bawahan; delegasi, kaderisasi.

\section{B. Credible}

a Integritas tinggi; jujur; satu kata dengan perbuatan (konsisten)

b Dapat dipercaya (reliable); dapat diandalkan (capable)

c Bertanggungjawab; menepati janji (komitmen); disiplin

d Berwatak baik; berniat baik; berpikir positif.

e Ber-etika bisnis bersih; transparan (keterbukaan)

f Berjalan sesuai regulasi (pemerintah, stakeholders, shareholders)

g Loyal; setia pada lembaga \& profesi; dedikatif

h Fair (tidak curang)

\section{Competent}

a Profesional, menguasai bidang profesinya

b Berorientasi pada kinerja dan hasil terbaik; get things done; bekerja tuntas

c Menggunakan sumber daya secara optimal (efisien dan efektif: work smart) 
d Berwawasan luas

e Senantiasa mengembangkan diri; continuous learning

f Proaktif

g Mengambil keputusan dengan arif; pertimbangan matang.

h Bekerjasama demi hasil terbaik bersama tim (sinergi; aliansi strategik; involving; teamwork)

i Trampil teknologi

\section{Competitive}

a Bersemangat kompetisi, bersaing secara smart; mencapai yang terbaik

b Kreatif, inovatif

c Percaya diri, berani memimpin,merintis,memulai

d Berani ambil risiko, speed, akseleratif

e Open minded, terbuka terhadap kritik, perbaikan dan perubahan.

f Tidak puas dengan kondisi saat ini, ingin berubah menjadi lebih baik

g Mengelola jejaring /networking yang semakin world wide

\section{E. Customerdelight}

a Berorientasi pada penyediaan layanan \& produk berkualitas sesuai kebutuhan pelanggan.

b Mempelajari kecenderungan dinamika kebutuhan pelanggan; fleksibilitas demi pelanggan

c Menangani keluhan dan problem pelanggan secara profesional

d Memahami/ mengantisipasi kebutuhan pelanggan (customer care) sebelum meminta

e Mengupayakan pelanggan semakin terdidik dan tercerahkan

f Menyenangkan pelanggan berdasarkan mentalitas berkelimpahan (aspek dua arah).

\section{Analisa Metode Penilaian Kepuasan Pelanggan TB. Gramedia Balekota}

Untuk memberikan pelayanan kepada pelanggan, TB. Gramedia Balekota telah melakukan pembekalan kepada seluruh karyawan dengan nilai dasar 5C seeperti yang sudah diurakan sebelumnya. Akan tetapi dalam pelaksanaan penilaian tingkat kepuasan pelanggan TB. Gramedia Balekota belum merumuskan indikator penilaian yang mencakup lima aspek kualitas pelayanan.

Metode Servqual Menurut Parasuraman et al. (1998) dalam Lupiyoadi (2014:216) menyatakan bahwa dimensi kualitas layanan (SERVQUAL) terdiri dari lima dimensi, yaitu:

a. Berwujud (tangible), yaitu kemampuan suatu perusahaan dalam menunjukkan eksistensinya kepada pihak eksternal. Penampilan dan kemampuan sarana dan prasarana fisik perusahaan yang dapat diandalkan, keadaan lingkungan sekitarnya merupakan bukti nyata pelayanan yang diberikan. Hal yang meliputi fasilitas fisik seperti gedung, gudang, perlengkapan dan peralatan yang digunakan serta penampilan pegawai.

b. Reliabilitas (Reliability), yaitu kemampuan perusahaan untuk memberikan pelayanan sesuai dengan yang dijanjikan secara akurat dan terpercaya. Kinerja harus sesuai dengan harapan pelanggan yang berarti ketepatan waktu, pelayanan yang sama untuk semua pelanggan tanpa kesalahan, sikap yang simpati, dan dengan akurasi yang tinggi.

c. Ketanggapan (responsiveness), yaitu suatu kebijakan untuk membantu dan memberikan pelayanan yang cepat (responsif) dan tepat kepada pelanggan dengan penyampaian informasi 
yang jelas. Membiarkan konsumen menunggu merupakan persepsi yang negatif dalam kualitas pelayanan.

d. Jaminan dan kepastian (assurance), yaitu pengetahuan, kesopanan-santunan dan kemampuan para pegawai perusahaan untuk menumbuhkan rasa percaya para pelanggan kepada perusahaan. Hal ini meliputi beberapa komponen antara lain komunikasi (communication), kredibilitas (credibility), keamanan (security), kompetensi (competence), dan sopan santun (courtesy).

e. Empati (empaty), yaitu memberikan perhatian yang tulus dan bersifat individual atau pribadi yang diberikan kepada para pelanggan dengan berupaya memahami keinginan konsumen. Setiap perusahaan diharapkan memiliki pengertian dan pengetahuan tentang pelanggan, memahami kebutuhan pelanggan secara spesifik, serta memiliki waktu pengoperasian yang nyaman bagi pelanggan.

Table 3. berikut menjelaskan perbandingan lima aspek penilaian metode Servqual dengan aspek penilaian yang digunakan TB.Gramedia balekota dalam melakukan pengukuran kepuasaan pelanggan. Dari tabel tersebut dapat diketahui bahwa nilai dasar yang dimiliki TB.Gramedia sebagai pedoman bagi seluruh karyawan dalam bersikap, berfikir dan bertidak hampir memenuhi lima aspek kualitas pelayanan servqual. Hanya aspek Tangible saja yang tidak ada karna 5C itu sendiri adalah nilai dasar bagi karyawan sedangkan aspek Tangible adalah Hal yang meliputi fasilitas fisik seperti gedung, gudang, perlengkapan dan peralatan yang digunakan.

Tabel 3. Perbandingan dimensi pengukuran kualitas pelayanan

\begin{tabular}{|c|l|}
\hline $\begin{array}{c}\text { Aspek penilaian } \\
\text { kepuasaan pelanggan } \\
\text { TB. Gramedia Balekota }\end{array}$ & $\begin{array}{l}\text { Lima Aspek } \\
\text { metode servqual }\end{array}$ \\
\hline \multirow{2}{*}{$\begin{array}{c}\text { Puas (Smile) } \\
\text { Biasa (Flat) }\end{array}$} & Tangible \\
\cline { 2 - 2 } Jelek $($ Sad $)$ & Reliability \\
\cline { 2 - 2 } & Assurance \\
\cline { 2 - 2 } & Empaty \\
\hline
\end{tabular}

TB.Gramedia Balekota dalam kusionernya guna mengukur kepuasan pelanggan menggunakan indikator yang masih sangat umum. Penilaian "puas, biasa atau jelek" yang diberikan oleh pelanggang masih belum bisa diterjemahkan kedalam reaksi nyata sebagai respon dari penilaian tersebut. Hal ini karena pihak manajemen TB.Gramedia Balekota belum dapat mengidentifikasi dari aspek mana penilaian itu diberikan, apakah dari aspek tangible, reliability, responsiveness, assurance atau empaty.

\section{KESIMPULAN DAN SARAN}

\section{Kesimpulan}

Teknik pengukuran kepuasan pelanggan yang digunakan TB. Gramedia Balekota belum dapat memberikan data kepuasan pelanggan yang optimal karena selain belum memenuhi kelima aspek metode servqual. indikator yang digunakan TB. Gramedia Balekota juga belum spesifik untuk dijadikan indikator penilaian karena belum dapat mengidentifikasi dari aspek mana penilaian itu diberikan, apakah dari aspek tangible, reliability, responsiveness, assurance atau empaty.

\section{Saran}

Berdasarkan hasil analisa dan pembahasan serta kesimpulan yang ada maka penulis memberikan beberapa saran yang dapat dijadikan masukan untuk TB. Gramedia Balekota dalam melakukan pengukuran kepuasaan pelanggan guna meningkatkan kualitas pelayanan. Adapun beberapa saran yang penulis bias berikan yaitu sebagai berikut:

a. Kelima aspek dari kualitas pelayanan yaitu Tangible, Reliability, Responsivenessi, Assurance, Empaty adalah aspek kepuasaan pelanggan sehubung dengan hal tersebut TB. 
Gramedia Balekota perlu memasukan kelima aspek tersebut kedalam kusioner sebagai penilaian kepuasan pelanggan .

b. Berikut contoh indikator dari masing-masig lima aspek penilaian tersebut :

1. Indikator aspek Tangible:
a. ketersediaan produk
b. kualitas produk
c. Kemudahan mencari buku
d. Penataan ruangan

2. Indikator aspek Reliability :

a. Kecepatan pegawai dalam memberikan pelayanan

b. Penanganan dengan segera setiap keluhan konsumen

c. Kecukupan informasi yang diterima konsumen

3. Indikator aspek Responsiveness :

a. Daya tanggap karyawan dalam melayani konsumen

4. Indikator aspek Assurance :
a. Kesopanan dalam pelayanan
b. Terampil dalam pelayanan
c. Pengetahuan dan wawasan karyawan.

5. Indikator aspek Empaty:

a. Pemberian pelayanan yang ramah dan menyenangkan

b. Memahami kebutuhan dan keinginan konsumen

c. Sikap simpatik pelayan terhadap terhadap maslah konsumen.

Pemilihan indikator mana yang akan digunakan tentunya harus melibatkan para pihak yang sangat memahami pada bidangnya, serta setipa indikator harus melalui uji validitas dan reliabilitas.

\section{DAFTAR PUSTAKA}

Bari dan Satria ( 2014). " Pengaruh Kualitas Pelayanan Terhadap Kepuasan Pelanggan dalam Berbelanja di Cak-Cuk Surabaya”. Jurnal Ilmu \& Riset Manajemen Vol. 3 No. 12.

Hadiati S. dan R. Sarwi. 2001. "Analisis Kinerja Kualitas Pelayanan Terhadap Kepuasan Pelanggan pada Telkomsel Malang Area”. Jurnal Manajemen dan Kewirausahaan. Vol.1, No. 1, September $1999: 56-64$.

Kotler. P. 2007. "Manajemen Pemasaran" . Edisi Milenium. PT. Prehallindo. Jakarta.

Ratmito \& Atik Winarsih. (2005). "Manajemen Pelayanan”. Yogyakarta: Pustaka Pelajar.

Sugiyono. 2007. "Metode Penelitian Bisnis". Penerbit CV. Alfabeth. Bandung.

Sugiyono. (2012). "Memahami Penelitian Kualitatif". Bandung: Alfabeta.

Swastha. B., dan H. Handoko. 2008. "Manajemen Pemasaran, Analisis Perilaku Konsumen “. BPFE. Yogyakarta.

Tjiptono, Fandy. (2009). “Service Marketing: Esensi dan Aplikasi”. Yogyakarta: Marknesis.

Vernon, Mark. (2011).” Business The Key Concept". Jakarta: PT Raja Grafindo Persada. 